\title{
ANTIHISTAMINIC ACTIVITY MODELS
}

\author{
PRIYA GUPTA, VANITA G KANASE*, SHALAKA KADAM, SALMAN KAPADIA, FALAK BAMNE
}

Department of Pharmacology, Oriental College of Pharmacy, Sanpada West, Navi Mumbai, Maharashtra, India. Email: vanita.kanase@gmail.com

Received: 23 April 2020, Revised and Accepted: 05 June 2020

\section{ABSTRACT}

Histamine is referred to as common allergic reactions and symptoms. Most of them are compared to histamine intolerance. Some common responses involved with this intolerance may vary but include headaches or migraines, nasal congestion or sinus problems, fatigue, hives, digestive problems, irregular menstrual cycle, nausea, and vomiting. Histamine is derived from a natural amino acid, S-histidine, through the histidine decarboxylase/ aromatic decarboxylase catalysis. Histamine is the compound that the mast cellgenerates for the immune response. Histamine promotes gastrointestinal secretion and induces capillary dilation, bronchial smooth muscle constriction, and reduced blood pressure. Antihistamines are medicinal products to treat allergic rhinitis and allergies. This includes the in vitro animal model and in-vivo tissue preparation antihistaminic activity. Animal models are significant instruments for understanding the pathological process of human illnesses in experimental medical science. Medicines associated with antihistamine include antiallergy, antivertigo, antimigraine, sedatives, antiemetic, etc. Elderly people are much more likely than youthful people to develop sleepiness from the use of antihistamines. The most common drugs used are cetirizine, levocetirizine, chlorpheniramine, diphenhydramine, loratadine, cimetidine, and fexofenadine. Animal models include histamine-induced bronchoconstriction, passive paw anaphylaxis, milk-induced leukocytosis and eosinophilia, clonidine, and haloperidol-induced catalepsy. While tissue models include isolated goat, and guinea-pig trachea chain preparation, as well as an isolated guinea pig, rat, mice ileum tissue preparation, and the dose-response curve of histamine, were plotted. The focus of the study had been on herbal plants and medicinal products, as they can effectively boost a variety of circumstances without significant adverse side effects. We can assess antihistaminic activity by using plant extracts or any synthetic drug.

Keywords: Histamine, Antihistaminic activity, Allergic rhinitis, Asthma, bronchoconstriction, Leukocytosis, Eosinophilia.

(C) 2020 The Authors. Published by Innovare Academic Sciences Pvt Ltd. This is an open access article under the CC BY license (http://creativecommons. org/licenses/by/4. 0/) DOI: http://dx.doi.org/10.22159/ajpcr.2020.v13i8.38016

\section{INTRODUCTION}

Asthma is a common recurrent airway disease that is characterized by complex and persistent signs, reversible fluid restriction, and spasms. Allergy is one of the growing illnesses with various symptoms that influence humanity. Histamine is available in the mucosa of human nasal turbinates and lungs which is in charge of bronchoconstrictive reactions [1-4]. Histamine causes the manifestation of hypersensitive responses that, for the most part, include intense irritation by the $\mathrm{H} 1$ histamine receptor [5,6].

In every cell, there are four types of histamine receptors, that is, H1, $\mathrm{H} 2, \mathrm{H} 3$, and H4 [7]. Antihistamines (H1) structure a noteworthy helpful class of medications utilized in the treatment of an assortment of hypersensitive conditions such as rhinitis, urticaria, roughage fever, and even asthma [8,9]. Since their revelation and early improvement during the 1940s, histamine $\mathrm{H} 1$ receptor foes (antihistamines) have turned out to be one of the most broadly utilized classes of drugs for unfavorably susceptible issues [10]. More established original antihistamines show high restricting fondness for $\mathrm{H} 1$ receptors, yet a large number of these medications display restricting partiality for different classes of cell receptors, for example, the muscarinic cholinergic subtypes (M1M5) [11]. More up to this point, second-age antihistamines were created as moderately more particular histamine $\mathrm{H} 1$ receptor opponents than the initial operators, with some extent of limiting midway intervened impacts, as an example, sedation. Nonetheless, doubtlessly a portion of the fresher antihistamines is appropriate official to muscarinic receptors, just as to histamine $\mathrm{H} 1$ receptors in the cerebrum [12].

Another trademark highlight of the more established antihistamines is that they access the mind and tie to cell receptors within the central nervous system (CNS), causing sedation and disabled psychomotor execution [13]. The old-style antihistamines are linked to localized infection symptoms $[14,15]$. Histamine is one of the most prevalent inflammatory mediators; it triggers symptoms of allergic reactions, most of which involve severe $\mathrm{H} 1$ histamine-mediated inflammation $[16,17]$. The histamine $\mathrm{H} 1$ receptor is predominantly found in endothelial cells, soft muscle tissue, and neuro and adds to dilatation of blood vessels, enhanced capillary permeability, and cellular level pressure, thus causing increased intracellular calcium (Ca2+) and nitric oxide (NO) output at the molecular level [18-20].

\section{MODELS FOR SCREENING OF ANTIHISTAMINIC ACTIVITY}

In-vivo model/animal model

1. Histamine-induced bronchoconstriction in guinea pigs/mice/rats.

2. Passive paw anaphylaxis in rats/guinea pig/mice.

3. Milk-induced leukocytosis in mice.

4. Milk-induced eosinophilia in mice.

5. Clonidine-induced catalepsy in mice.

6. Haloperidol-induced catalepsy in mice.

\section{In-vitro model/tissue model}

1. Isolated goat trachea chain preparation.

2. Isolated guinea pig trachea chain preparation.

3. Guinea pig ileum tissue preparation.

4. Rat/mice ileum tissue preparation.

\section{IN-VIVO MODEL/ANIMAL MODEL}

1. Histamine-induced bronchoconstriction in guinea pigs/mice/rats Animals were split into eight groups $(n=6)$, the control group provided distilled water and a single extract dose was offered to other groups $(75,150,200,300,600$, and $1200 \mathrm{mg} / \mathrm{kg}$ p.o.). chlorprheniramine maleate $(2 \mathrm{mg} / \mathrm{kg})$ serve as a positive control. Pre- and postmedication treatment, each animal was kept within the histamine chamber and subjected to $0.2 \%$ histamine aerosol. The pre-convulsive 
period (PCT) was calculated from the moment of initiation to the start of dyspnoea, contributing to the appearance of pre-convulsive dyspnoea within a min.

The percentage of protection offered by PCT drugs was determined for each dosage and positive control. The percentage protection was calculated using the formula below [21-31].

Percentage protection $=(1-\mathrm{T} 1 / \mathrm{T} 2) \times 100$

Where T1 $=$ PCT average before test drug administration and

$\mathrm{T} 2=\mathrm{PCT}$ average after test drug administration

2. Passive paw anaphylaxis in rats/guinea pig/mice

On days 1,3 , and 5 , animals got subcutaneously $100 \mu \mathrm{g}$ of egg white. Blood was gathered from the retro-orbital plexus and centrifuged to isolate serum on the $10^{\text {th }}$ day of sensitization. It was entitled to clot the gathered blood and at $1500 \mathrm{rpm}$ the serum was divided by centrifugation. Animals in eight groups $(n=6)$ were divided. The saline solution got by the control group and other groups were given a singular concentrate portion of $85,175,250,350,700$, and $1400 \mathrm{mg} /$ $\mathrm{kg}$ p.o. Dexamethasone $(0.27 \mathrm{mg} / \mathrm{kg}$ p.o.) was utilized as a standard. Animals were sensitized with serum into the left hind paw before medication therapy. The right hind paw got the same normal saline solution quantity. The animals were examined with $10 \mu \mathrm{g}$ of egg white in $0.1 \mathrm{ml}$ of normal saline solution in left paw 1-h post-administration of the study drug and the paw expansion using a plethysmometer was assessed. Following $24 \mathrm{~h}$, the level of edema restraint was determined to utilize the equation underneath [32-34],

Inhibition rate $=[1-(\mathrm{T} / \mathrm{C})] 100$

$\mathrm{T}$ - Average relative difference in paw volume (test group).

$\mathrm{C}$ - Average relative difference in paw volume (control group).

3. Milk-induced leukocytosis in mice

Mice (Swiss Albino) were split into six categories with each category containing six mice. Blood samples were obtained using pentobarbital sodium (i.p.), using RO (retro-orbital) vein under sedation. Class 1 served as normal control, Class 2 that received milk served as an intoxicant, Class 3 received standard as dexamethasone, and Class 4 to Class 6 received extract dose in low, moderate, and high dose. All classes got boiled and cooled milk infusion in the dose of $4 \mathrm{ml} / \mathrm{kg}$ s.c. after 30 min of drug treatment, excluding the normal control group.

Total leukocyte counts were conducted in each class before test compound administration and $24 \mathrm{~h}$ after milk infusion.
Calculate the change in total leukocytes count pre and post $24 \mathrm{~h}$ drug administration (Table 1) [35-39].

4. Milk-induced eosinophilia in mice

Mice (Swiss Albino) were split into six categories with each category containing six mice. Blood samples were obtained using pentobarbital sodium (i.p.), using RO (retro-orbital) vein under sedation. Class 1 served as normal control, Class 2 that received Milk served as an intoxicant, Class 3 received standard as dexamethasone, and Class 4 to Class 6 received extract dose in low, moderate, and high dose. All classes got boiled and cooled milk infusion in the dose of $4 \mathrm{ml} / \mathrm{kg}$ s.c. after $30 \mathrm{~min}$ of drug treatment, excluding the normal control group.

Total eosinophil counts were conducted in each class before test compound administration and $24 \mathrm{~h}$ after milk infusion.

Calculate the change in total leukocytes count pre and post $24 \mathrm{~h}$ drug administration (Table 1) [37,40-43].

5. Clonidine-induced catalepsy in mice

Mice (Swiss Albino) were split into five classes containing 5 mice each. Normal control (Class 1) provided saline solution $(10 \mathrm{ml} / \mathrm{kg}$ ) and other Class 3 to Class 5 received a single dosage of extract $(100$, 200 , and $400 \mathrm{mg} / \mathrm{kg}$ body weight). Mice of Class 2 got standard dose chlorpheniramine maleate (antihistamine) (10 mg/kg, i.p.). One hour after intake of the drug, all the classes got clonidine $(1 \mathrm{mg} / \mathrm{kg} \mathrm{s.c.})$, and the catalepsy period was determined at $15 \mathrm{~min}, 30 \mathrm{~min}, 60 \mathrm{~min}, 90 \mathrm{~min}$, $120 \mathrm{~min}, 150 \mathrm{~min}$, and $180 \mathrm{~min}$ (Table 2) [44,45]

\section{Haloperidol-induced catalepsy in mice}

Mice (Swiss Albino) were split into five classes containing five mice each. Normal control (Class 1) provided saline solution $(10 \mathrm{ml} / \mathrm{kg})$ and other Class 3 to Class 5 received a single dosage of extract $(100$, 200 , and $400 \mathrm{mg} / \mathrm{kg}$ body weight). Mice of Class 2 got standard dose chlorpheniramine maleate (antihistamine) (10 mg/kg, i.p.). One hour after intake of the drug, all the classes got haloperidol (1 mg/kg s.c.), and the catalepsy period was determined at $15 \mathrm{~min}, 30 \mathrm{~min}, 60 \mathrm{~min}, 90$ min, $120 \mathrm{~min}, 150 \mathrm{~min}$, and $180 \mathrm{~min}$ (Table 3) [22,46]

\section{Bar test scoring}

The bar test was used for catalepsy measurements. In the bar test, the animal's front paw was placed alternatively on a horizontal bar 3 $\mathrm{cm}$ above and $5 \mathrm{~cm}$ parallel to the foundation. The moment the mice removes its front paw from the bar were observed.

Table 1: Animal grouping for milk-induced leukocytosis and eosinophilia study [37,40-43]

\begin{tabular}{llll}
\hline Class & Test substance & Albino mice per group & Dose as required \\
\hline 1 & Normal saline & 6 & $\mathrm{ml} / \mathrm{kg}$ \\
2 & Milk & 6 & $\mathrm{mg} / \mathrm{kg}$ \\
3 & Milk+Dexamethasone & 6 & $\mathrm{mg} / \mathrm{kg}$ \\
4 & Milk+Extract (Low dose) & 6 & $\mathrm{mg} / \mathrm{kg}$ \\
5 & Milk+Extract (Moderate dose) & 6 & $\mathrm{mg} / \mathrm{kg}$ \\
6 & Milk+Extract (High dose) & 6 & $\mathrm{mg} / \mathrm{kg}$ \\
\multicolumn{2}{l}{ Total animals required } & & 6 \\
\hline
\end{tabular}

Table 2: Animal grouping for clonidine-induced catalepsy study $[44,45]$

\begin{tabular}{|c|c|c|c|c|}
\hline Class & Test substance & Albino mice per group & Dose as required & Total \\
\hline 1 & Normal saline+clonidine & 5 & $\mathrm{ml} / \mathrm{kg}$ & 5 \\
\hline 2 & Standard+clonidine (chlorpheniramine maleate) & 5 & $\mathrm{mg} / \mathrm{kg}$ & 5 \\
\hline 3 & Extract+clonidine (LOW DOSE) & 5 & $\mathrm{mg} / \mathrm{kg}$ & 5 \\
\hline 4 & Extract+clonidine (medium dose) & 5 & $\mathrm{mg} / \mathrm{kg}$ & 5 \\
\hline 5 & Extract+clonidine (high Dose) & 5 & $\mathrm{mg} / \mathrm{kg}$ & 5 \\
\hline \multicolumn{4}{|c|}{ Total animal required } & 25 \\
\hline
\end{tabular}


Table 3: Animal grouping for haloperidol-induced catalepsy study $[22,46]$

\begin{tabular}{|c|c|c|c|c|}
\hline Class & Test substance & Albino mice per group & Dose as required & Total \\
\hline 1 & Normal saline+haloperidol & 5 & $\mathrm{ml} / \mathrm{kg}$ & 5 \\
\hline 2 & Standard+haloperidol (chlorpheniramine maleate) & 5 & $\mathrm{mg} / \mathrm{kg}$ & 5 \\
\hline 3 & Extract+haloperidol (low dose) & 5 & $\mathrm{mg} / \mathrm{kg}$ & 5 \\
\hline 4 & Extract+haloperidol (medium dose) & 5 & $\mathrm{mg} / \mathrm{kg}$ & 5 \\
\hline 5 & Extract+haloperidol (high dose) & 5 & $\mathrm{mg} / \mathrm{kg}$ & 5 \\
\hline \multicolumn{4}{|c|}{ Total animal required } & 25 \\
\hline
\end{tabular}

\section{Catalepsy valuing was given as follows}

- $\quad$ Step 1: The mice were removed from the house cage and placed on the table. If the mice did not move, a value of 0.5 was allocated when touched or softly pushed back.

- $\quad$ Step 2: The mice's front paws were alternatively put on a $3 \mathrm{~cm}$ long bar. If the mice did not correct the posture within $15 \mathrm{~s}$, for each paw a value of 0.5 was added to the value of Step 1 .

- Step 3: The mice's front paws were alternatively put on a $5 \mathrm{~cm}$ long bar, if the mice did not correct the posture within $15 \mathrm{~s}$, on each paw a value of 1 was added to the value of Step 1 and 2 .

\section{Formula to calculate catalepsy value}

Total value $=0.5+[0.5 \times$ time (in s) of front right paw on $3 \mathrm{~cm}$ long bar $]$ $+[0.5 \times$ time (in s) of front left paw on $3 \mathrm{~cm}$ long bar $]+[1 \times$ time (in s) of front right paw on $5 \mathrm{~cm}$ long bar $]+[1 \times$ time (in s) of front left paw on $5 \mathrm{~cm}$ long bar]

\section{IN-VITRO MODEL}

\section{Isolated goat trachea chain preparation}

From the adult goat, isolated tracheal tissue was acquired instantly after the animals were slaughtered. Tracheal was cut into separate pieces and sequentially connected to form a chain. In Krebs bathwater, trachea was suspended and constantly aerated at $37 \pm 0.5^{\circ} \mathrm{C}$. At one end of the prepared tracheal chain was connected to the s-shaped aerator pipe and another end connected to an isotonic frontal writing lever. The histamine dose-response curve (DRC) was traced on the kymographic sheet that is mounted on a revolving drum.

A graphic of the largest percentage of contractile responses to histamine ordinate and abscissa concentration was considered for the screening of histamine DRC in the lack and existence of drug extract [47-55].

2. Isolated guinea pig trachea chain preparation

From the guinea pig, isolated tracheal tissue was acquired instantly after the animals were slaughtered. The trachea was cut into separate pieces and sequentially connected to form a chain. In Krebs bathwater, trachea was suspended and constantly aerated at $37 \pm 0.5^{\circ} \mathrm{C}$. At one end of the prepared tracheal chain was connected to the s-shaped aerator pipe and another end connected to an isotonic frontal writing lever. The histamine dose-response curve (DRC) was traced on the kymographic sheet that is mounted on a revolving drum.

A graphic of the largest percentage of contractile responses to histamine ordinate and abscissa concentration was considered for the screening of histamine DRC in the lack and existence of drug extract [55-58].

3. Guinea pig/rabbit ileum tissue preparation

The guinea pigs/rabbit which were fasted overnight were sacrificed and the ileum was put in an organ bath with a Tyrode solvent that was constantly aerated at $37 \pm 0.5^{\circ} \mathrm{C}$. The histamine dose-response curve was carried out in the plain Tyrode solvent and in the extract-containing Tyrode solvent. The largest percentage of contractile responses in the lack and existence of the extract was intended to generate the histamine dose-response curve [59-61].

4. Rat/mice ileum tissue preparation

The rat/mice which were fasted overnight were sacrificed and the ileum was put in an organ bath with a Tyrode solvent that was constantly aerated at $37 \pm 0.5^{\circ} \mathrm{C}$. The histamine dose-response curve was carried out in the plain Tyrode solvent and in the extract-containing Tyrode solvent. The largest percentage of contractile responses in the lack and existence of the extract was intended to generate the histamine doseresponse curve [59,62-66].

\section{Tissue preparation}

Before 1 day of the start of the study, the animals were dieted overnight with free water exposure. Animals had been killed humanly by ether under sedation. The cervical dislocation slaughtered animals were used. About $1 \mathrm{~cm}$ from the ileocaecal junction, a $3 \mathrm{~cm}$ portion of the ileum was surgically removed. As described earlier, the transverse tissue sheet had been removed. Nearly $1.5 \mathrm{~cm}$ long strips were set in 5 ml organ water containing Krebs-Henseleit arrangement with 95\% 02 and $5 \% \mathrm{CO}_{2}$ and held at $37^{\circ} \mathrm{C}$.

Tissue was fixed, with the aid of two tight loops. At one end of the prepared tracheal chain was connected to the s-shaped aerator pipe and another end connected to an isotonic frontal writing lever. Before the procedures began, the tissue strips were balanced for 45 min under resting stress of $1 \mathrm{~g}$. Tissue responses, that is, histamine dose-response curve, had been traced on kymographic paper [67].

\section{CONCLUSION}

Asthma is an immune-involved inflammatory disease. Treatment includes many factors that are capable of managing asthma. The current research was scheduled to assess the effect of the extract on different elements of asthma, such as bronchoconstriction, eosinophilia, and inflammation-related allergy using different animal models in vitro and in vivo.

Recently, as innovative clinical strategies for the research of antihistaminic disease and its related disorders, many herbal plants and medicinal items have received research interest because they can effectively improve a variety of circumstances without severe adverse side effects.

\section{ACKNOWLEDGMENT}

We are thankful for their guidance and help to our Principal, Dr. (Mrs.) Sudha Rathod, Dr. (Mrs.) Vanita G. Kanase, Mr. Imtiyaz Ansari, and Mrs. Pushplata Chougale as well as to the Department of Pharmacology, Oriental College of Pharmacy, Navi Mumbai.

\section{AUTHORS' CONTRIBUTIONS}

We declare that this work was done by the authors named in this article and all liabilities about claims relating to the content of this article will be borne by the authors. Ms. Priya Gupta, Ms. Shalaka Kadam, Mr. Salman Kapadia, and Ms. Falak Bamne collected the data and analyzed the data. Dr. (Mrs.) Vanita Kanase proofread the whole manuscript and suggested the necessary changes, and helps in designing the manuscript.

\section{CONFLICTS OF INTEREST}

The authors declare that there are no conflicts of interest regarding the publication of this paper. 


\section{AUTHORS' FUNDING}

We thank Oriental College of Pharmacy for funding the project.

\section{REFERENCES}

1. Casale T, Rodbard D, Kaliner M. Characterization of histamine H1-receptors on human peripheral lung. Biochem Pharmacol 1985;34:3285-92.

2. Herxheimer $\mathrm{H}$. Antihistamines in bronchial asthma. $\mathrm{Br}$ Med $\mathrm{J}$ 1949;2:901-5.

3. Wood-Baker R, Holgate S. The comparative actions and adverse effect profile of single doses of H1-receptor antihistamines in the airways and skin of subjects with asthma. J Allergy Clin Immunol 1993;91:1005-14.

4. Schmidt D, Ruehlmann E, Branscheid D, Magnussen H, Rabe KF. Passive sensitization of human airways increases responsiveness to leukotriene C4. Eur Respir J 1999;14:315-9.

5. Orzechowski RF, Currie DS, Valancius CA. Comparative anticholinergic activities of 10 histamine $\mathrm{H} 1$ receptor antagonists in two functional models. Eur J Pharmacol 2005;506:257-64.

6. Slater JW, Zechnich AD, Haxby DG. Second-generation antihistamines: A comparative review. Drugs 1999;57:31-47.

7. Zaseem K, Imitiyaz A, Vanita K. Evaluation of antihistaminic activity. World J Pharm Res 2018;7:278-88.

8. Saxena AK, Saxena M. Developments in antihistaminics (H1). In: Progress in Drug Research. Basel: Ernst Jucker; 1992. p. 35-126.

9. Shishoo CJ, Shirsath VS, Rathod IS, Vikas D. Design, synthesis and antihistaminic (H1) activity of some condensed, 3-aminopyrimidin4(3H)-ones. Yande Eur J Med Chem 2000;35:351-8.

10. Kubo N, Shirakawa O, Kuno T, Tanaka C. Antimuscarinic effect of antihistamines: Quantitative evaluation by receptor binding assay. Jpn J Pharmacol 1987;43:277-82.

11. Laak AM, den Kelder GM, Bast A, Timmerman H. Is there a difference in the affinity of histamine $\mathrm{H} 1$ receptor antagonists for CNS and peripheral receptors? An in vitro study. Eur J Pharmacol 1993;232:199-205.

12. Hindmarch I, Shamsi Z. Antihistamines: Models to assess sedative properties, assessment of sedation, safety and other side-effects. Clin Exp Allergy 1999;29:133-42.

13. Garrison JC. Histamine, bradykinine, 5-hydroxytryptamine and their antagonists. In: Gilman AG, Rall TE, Nies AS, Taylor P, editors. The Pharmacological Basis of Therapeutics. $8^{\text {th }}$ ed. New York: Pergamon Press; 1990. p. 575.

14. Green JP, Weinstein H. Psychopharmacology: A Generation of Progress. New York: Raven Press; 1978. p. 319.

15. Thurmond RL, Gelfand EW, Dunford PJ. Review: The role of histamine $\mathrm{H} 1$ and $\mathrm{H} 4$ receptors in allergic inflammation: The search for new antihistamines. Nat Rev Drug Discov 2008;7:41-53.

16. Yong YK, Zakaria ZA, Kadir AA, Somchit MN, Lian GE, Ahmad Z. Chemical constituents and antihistamine activity of Bixa orellana leaf extract. BMC Complement Alternat Med 2013;13:1-7.

17. Rozenberg I, Sluka SH, Rohrer L, Hofman J, Becher B, Akhmedov A, et al. Histamine $\mathrm{H} 1$ receptor promotes atherosclerotic lesion formation by increase vascular permeability for low-density lipoproteins. Arterioscler Thromb Vasc Biol 2010;30:923-30.

18. Mobarakeh JI, Sakurada S, Katsuyama S, Kutsuwa M, Kuramasu A, Lin ZY, et al. Role of histamine H1 receptor in pain perception: A study of the receptor gene knockout mice. Eur J Pharmacol 2000;391:81-9.

19. Jutel M, Akdis M, Akdis CA. Histamine, histamine receptors and their role in immune pathology. Clin Exp Allergy 2009;39:1786-800.

20. Singh S, Agrawal SS. Broncho-relaxant activity of Belamcanda chinensis. Indian J Pharmacol 1990;22:107-9.

21. Tripathi RM, Das PK. Studies on anti-asthmatic and anti-anaphylactic activity of Albizia lebbeck. Indian J Pharmacol 1977;9:189.

22. Kumar D, Bhujbal SS, Deoda RS, Mudgade SC. In-vitro and in-vivo antiasthmatic studies of Ailanthus excelsa Roxb. On guinea pigs. J Sci Res 2010;2:196-202

23. Gokhale AB, Saraf MN. Bronchoprotective effect of ethanolic extract of Tephrosia purpurea in-vivo. Indian Drugs 1996;37:346-7.

24. Evans WC, Trease EV. Pharmacognosy. $14^{\text {th }}$ ed. London: W.B. Sunders Company; 1997. p. 250-1.

25. Nimgulkar CC, Patil SD, Kumar BD. Anti-asthmatic and antianaphylactic activities of Blatta orientalis mother tincture. Homeopathy 2011;100:138-43

26. Okpo SO, Eze GI, Ajaanonwu IH, Ijei OL, Uwaya DO, Ologe V. Evaluation of the anti-asthma activity of aqueous root, bark extract of Ficus exasperata Vahl (Moraceae). Int J Health Res 2012;5:5-12.
27. Sharma P, Hullatti KK, Kuppasth IJ, Sharma S. Studies on anti-asthmatic property of Cyamopsis tetragonoloba (L.) Taub. Leaf extracts. J Natl Remed 2010;10:81-6.

28. Munish G, Chancal G. Effect of Phyllanthus urinaria in biochemical profile of experimental hyperglycemic albino rats. Res J Pharm Sci 2012;1:2-6.

29. Saxena P, Saxena P. In-vitro and in-vivo evaluation of anti-asthmatic activity of rhizomes extract of Acorus calamus (Linn.) in guinea pigs. Res J Pharm Sci 2014;2319:555.

30. Mitra SK, Gopumadhavan S, Venkataranganna MV, Anturlikar SD. Antiasthmatic and antianaphylactic effect of E-721B, a herbal formulation. Indian J Pharmacol 1999;31:133.

31. Slvvsn KS, Anbu J, Anjana A, Sumithra M, Sathish R. Influence of ethanolic leaf extract of Sargassum wightii and Adiantum capillus on histamine induced asthma in animal model. Int J Pharm Pharm Sci 2012;4:121-3

32. Gosh MN. Fundamental of Experimental Pharmacology. $2^{\text {nd }}$ ed. Calcutta: Scientific Book Agency; 1984. p. 132

33. Kaushik D, Rani R, Kaushik P, Sacher D, Yadav J. In vivo and in vitro antiasthmatic studies of plant Piper longum Linn. Int J Pharmacol 2012;8:192-7.

34. Bhargava KP, Singh N. Antistress activity of Ocimum sanctum (linn). Indian J Med Res 1981;73:443-51.

35. Horn BR, Robin ED. Total eosinophils count in the management of bronchial asthma. N Engl J Med 1975;292:1152-5.

36. Mitra SK. Anti-asthmatic and anti-anaphylactic effect of e-721b: An herbal formulation. Indian J Pharmacol 1999;31:133-7.

37. Brekhman II, Dardymov IV. New substances of plant origin which increase nonspecific resistance. Annu Rev Pharmacol 1969;9:419-30.

38. Vadnere G, Somani R, Singhai AK. Studies on antiasthmatic activity of aqueous extract of Clerodendrum phlomidis. J Pharm Pharmacol 2006;58:164

39. Taur DJ, Nirmal SA, Patil RY, Karma MD. Antistress and antiallergic effects of Ficus benghalensis bark in asthma. Nat Prod Res 2007;21:1266-70.

40. Mali RG, Dhake AS. Evaluation of effects of Bauhinia variegata stem bark extracts against milk-induced eosinophilia in mice. J Adv Pharm Technol Res 2011;2:132

41. Rajasekaran S. Evaluation of effects of Parthenium hysterophorus 1, leaves extracts against, milk-induced eosinophilia in mice. Int J Pharm Sci Res 2014;5:1303-06.

42. Dusser D. Role of eosinophils in asthma. Rev Mal Respir 2000;17:195-201

43. Kumar D, Bhujbal SS, Patil PS, Buge PV. In-vitro and in-vivo activities of stem bark of methanolic extract of Ailanthus excelsa Roxb. In the management of asthma. Int J Pharmacol 2010;6:284-9.

44. Ferré S, Guix T, Prat G, Jane F, Casas M. Is experimental catalepsy properly measured? Pharmacol Biochem Behav 1990;35:753-7.

45. Kumar D, Bhat ZA, Singh P, Bhujbal SS, Deoda RS. Antihistaminic activity of aqueous extract of stem bark of Ailanthus excelsa Roxb. Pharmacogn Res 2011;3:220

46. Sanberg PR. Haloperidol-induced catalepsy is mediated by postsynaptic dopamine receptors. Nature 1980;284:472-3

47. Chaudhari KN, Lahiri SC. Role of goat trachea for an isolated tracheal chain preparation. Indian J Pharmacol 1974;6:149-51.

48. Kulshrestha S, Misra SS, Sharma AL, Sharma P, Singhal D. Response of the goat trachea to some autonomic drugs. Indian J Pharmacol $1983 ; 15: 107-10$

49. Kiritikar KD, Basu BD. Indian Medicinal Plants. $1^{\text {st }}$ ed. New Delhi: Periodical Experts Books Agency; 1991.

50. Nag CA, Lahiri SC. Use of goat trachea for an isolated tracheal chain preparation. Indian J Pharmacol 1974;6:149.

51. Hajare R, Darvhekar VM, Shewale A, Patil V. Evaluation of antihistaminic activity of piper betel leaf in guinea pig. Afr J Pharm Pharmacol 2011;5:113-7

52. Castillo JC. The tracheal chain: I. A preparation for the study of antispasmodics with particular reference to bronchodilator drugs. J Pharmacol Exp Ther 1947;90:104-9.

53. Patil SD, Ahale SV, Surana SJ. Evaluation of antiasthmatic and antianaphylactic activity of Balanites aegyptiaca (delile), (balanitaceae). Asian J Pharm Clin Res 2011;4:52-5

54. Manekar SS, Manoj S. Evaluation of anti-asthmatic activity of methanolic extract of Barleria prionitis Linn. Aerial parts. Int J Curr Pharm Res 2018;10:30-4.

55. Sirisha K, Achaiah G, Rao AR. Design, synthesis and evaluation of new 2, 6-dihydroimidazo [1, 2-c] pyrimido [5, 4-e]-Pyrimidine-5 $(3 \mathrm{H})$ thiones as possible antihistaminic/antiasthmatic agents. Indian J Pharm 
Sci 2014;76:519.

56. Kaley G, Weiner R. Prostaglandin 'E'a potential mediator. Ann N Y Acad Sci 1971;180:347-8.

57. Sagar R, Sahoo HB. Evaluation of antiasthmatic activity of ethanolic extract of Elephantopus scaber L. leaves. Indian J Pharmacol 2012;44:398.

58. Ghosh MN. Fundamentals of Experimental Pharmacology. Kolkata, India: Scientific Book Agency; 1984. p. 60-3.

59. Singh N, Nath R, Gupta ML, Kohli RP. An experimental evaluation of anti-asthmatic potentialitis of Inula racemosa (Puskar Mul). Quart J Crude Drug Res 1980;18:89-96.

60. Pandit P, Singh A, Bafna AR, Kadam PV, Patil MJ. Evaluation of antiasthmatic activity of Curculigo orchioides Gaertn. Rhizomes. Indian J Pharm Sci 2008;70:440.

61. Nagarajan K, Sharan G, Jeshvanth A, Nightingale T, Dheeneswari P, Sumanthi A. Evaluation of anti-histaminic activity of leaves of Acalypha canescana in isolated ileum of rabbit. Int J Pharm Pharm Sci 2010;2:19-20.

62. Afreen A, Kashyap P, Sawarkar H, Deshmukh V, Upadhyay A, Pal S.
In-vitro and In-vivo models for evaluation of anti-asthmatic activity: A review. Int J Herbal Drug Res 2011;1:19-27.

63. Adusumalli SU, Ranjit PM, Harish MS. Antiasthmatic activity of aqueous extract of Pistacia integerrima galls. Int J Pharm Pharm Sci 2013;5 Supp1 2:116-21

64. Taur DJ, Patil RN, Patil RY. Antiasthmatic related properties of Abrus precatorius leaves on various models. J Tradit Complement Med 2017;7:428-32

65. Vogel GH, Vogel WH. Drug Discovery and Evaluation. Berlin: Spinger Verlag; 1998.

66. Butler A, Elswood CJ, Burridge J, Ireland SJ, Bunce KT, Kilpatrick GJ, et al. The pharmacological characterization of 5-HT3 receptors in three isolated preparations derived from guinea-pig tissues. Br J Pharmacol 1990;101:591-8.

67. Saikia B, Barua CC, Haloi P, Patowary P. Anticholinergic, antihistaminic, and antiserotonergic activity of n-hexane extract of Zanthoxylum alatum seeds on isolated tissue preparations: An ex vivo study. Indian J Pharmacol 2017;49:42. 